\title{
Scenario of industrial dispute in Jammu and Kashmir
}

\author{
Archana Bhat ${ }^{1, *}$, Ravikant Swami ${ }^{2}$ \\ ${ }^{1}$ Research Scholar, ${ }^{2}$ Professor, ARNI School of Business Management, ARNI University, Kathgarh, Indora, Himachal Pradesh, \\ India
}

*Corresponding Author:

Email: archanab_mba@yahoo.com

\begin{abstract}
The present endeavour focused on the industrial dispute scenario in J\&K state and with special emphasis on the causes of disputes in the cement industry in J\&K. The study found that over the period of time there has been gradual decline observed in the number of disputes in $J \& K$ but it has been experienced from the statistics that Jammu division is showing the presence of more disputes than other districts of the state. In addition to this, the study highlighted the issues namely recruitment, promotion and wages as the responsible factor for the causes of disputes in cement industry in J\&K state. To create a harmonious relationship in the organisations, the policy makers and management should take into consideration the people at younger age group with fair level of experience and qualification so as to make efficient output by utilization the most important assets of the organizations. The policy maker should take into consideration proper follow up for the disputes that come under the different acts and try to make the settlement machinery more effective and powerful so that the disputes are settled very effectively and efficiently.
\end{abstract}

Keywords: Industrial Dispute, Recruitment, Promotion, Wages and Allowances, Settlement Machinery.

\section{Introduction}

Human resource as the input is having the largest presence in the industry. To play a pivotal role for the growth and development of the industry, the effective and proper utilization of resources becomes an issue of concern. Without any emphasis on the excess to proper utilization of manpower the industry cannot think of growth in future. There have been various studies that indicate Indian labour laws are highly protective of labour, and labour markets are relatively inflexible and these laws apply only to the organised sector. Consequently, these laws have restricted labour mobility, have led to capital-intensive methods in the organised sector and adversely affected the sector's long-run demand for labour. Labour being a subject in the concurrent list, State-level labour regulations are also an important determinant of industrial performance. Evidence suggested that States, which have enacted more pro-worker regulations, have lost out on industrial production in general (Ministry of Finance, 2006, p.209).

The India cement industry is considered as one of the major industries in India. Being one of the oldest manufacturing industries, it is having the presence of capital and energy intensiveness. This industry is especially well endowed with all the essential raw materials, skilled labour/human resources, machinery, equipment, technology and know-how. Human resources besides other inputs viz. labour, capital, technology, raw materials etc. are considered as the most important input for the production of goods or services in different economies of world. It has been believed as the most valuable assets and the back bone of developed as well as well as developing economy in modern era. To manage such resources in the contemporary era is a growing concept. It is having the remarkable significance in the manufacturing industry especially.

As Indian economic scenario has been changing at the rapid pace and the organisations that are in operations in India are continuously looking into the psychological difference among the individuals thereby making changes in the management process. The poor understanding about the human resources and their relation in the organisations is thus going to lead towards the difficult implementation of other resources and cab build the hindrances toward the firm's ability to accept risk, being innovative and proactive in nature.

Ideally, an organization's culture and procedures should seek to avoid or resolve any potential conflict. A number of studies have been conducted on the different aspects of Industrial relation at national and international level. Kumar (1966) examined that the contributing factors for the ineffectiveness of settlement of disputes are lack of trust in conciliation machinery and the nature of politicized Trade Union. Singh (1983) found that the pay allowances and human resources are the dominant cause for strikes. Islam (1983) found that industrial relations are promoting or negating the overall economic growth of a country. Gani (1990) examined the industrial relation in Jammu and Kashmir. The study concluded that wages allowances are the major cause for the industrial disputes in the state. Nagaraju (1981); Murthy et al. (1986) and Asdhir (1987) concluded that conciliation machinery as a settlement tool of industrial conflicts has overall failed 
to contribute in the sphere of industrial relations. Sharma and Sidhu (2003) concluded that the lockout have been used as the powerful weapon the counter the increasing organised power of workers in Punjab. Katuwal (2011) suggested for voluntarily resolution a medium of settling the disputes. Pathania (2012) found that there is satisfactory industrial relation in India, due to the growth of trade union and continuous decline in industrial strikes and lockout.

The conceptual analysis concludes that though there has been discussion regarding the dispute settlement of manufacturing industries world widely and in India but very scant attention had been paid for measuring the factors responsible for the causes of the disputes in the Cement industry in Indian and in particular to Jammu and Kashmir. The present study has not only enriched the existing literature but has also provided an enhanced picture regarding the positions of industrial disputes with indicators in J\&K.

\section{Materials and Method \\ Objective of the Study}

The objective of the study is to identify the trend of various disputes in $\mathrm{J} \& \mathrm{~K}$.

\section{Type of Study}

The present study being descriptive in nature explored the meaningful results regarding the scenario of disputes in $\mathrm{J} \& \mathrm{~K}$.

\section{Source of Data}

For the analysis part various publications and annual report published by Ministry of Labour, Jammu and Kashmir State Industrial Development Corporation, District Industrial Centres, Labour Bureau of Government of India, and Reserve Bank of India, and Statistics Department of Jammu and Kashmir; Labour Commissioner Office Jammu and Kashmir has been used to explore the scenario of the disputes under different acts in Jammu and Kashmir. To analyse the trend of disputes in the J\&K state, 7 districts have been used that are having the presence of cement industries. In addition, the study has also used the primary data collected using the structured questionnaire. The information has been collected from the 17 cement industries operational in J\&K state.

To explore the nature of disputes and their settlement mechanism the study has not focus on various industries operational in the state but it has focused on the growing industry of the state after year 2012 i.e., cement industry. However, during 2017, there has been pressure on one of the public cement industry i.e., Jammu \& Kashmir Cement Ltd, to stop operation due to pollution where more than 1000 employees are working. There are more than 20 cement industries operations in the Jammu \& Kashmir state. These cement enterprises majorly operate in Jammu, Kathua, Samba, Udhampur, Srinagar and Reasi district of J\&K state.

\section{Period of Study}

To explore the trend and causes of disputes the study has incorporated the secondary data for different districts from 2001-11 and to identify the causes and the impact of various demographic indicators on the causes of disputes, the primary data has been collected in 2016-17 from 20 different cement industries operational in J\&K, respectively. The universe of the study is $J \& K$ state. Out of 20 companies, one was government cement industry and rest 19 were private.

\section{Sample Size}

Moreover, to analyse the scenario of disputes in J\&K, the study also conducted a primary survey for 289 respondents working in the cement industries of state. The study tried to explore the causes of disputes in the cement industry to highlight the scenario of conflicts prevailing in the most growing industry in the region.

\section{Results and Discussions}

The data collected from various secondary sources has helped in understanding the position of disputes in the state and the trend of resolving them over the period. Fig. 1 provides data in terms of number of disputes pending beginning of year, number of disputes received during the year, number of disputes settled during the year and number of disputes pending at the end of the year for the period 2001-2010. Disputes pending in the beginning of year have decreased from 11 to 7 during the year 2001-2003 but an increase to 17 in 2010-2011 has been observed. The number of disputes received has fluctuated during the years but during the year 2010-2011 an increase has been observed from 20 to 22 . The highest number of dispute received is 43 during 2004-2005. The number of disputes pending has also depicted an increase during 2002-2005 and decline from 26 to 9 during 2010-2011. Therefore, it can be concluded from the estimates observed from available secondary data is that the disputes settlement process is not so much effective in the state of Jammu and Kashmir. 


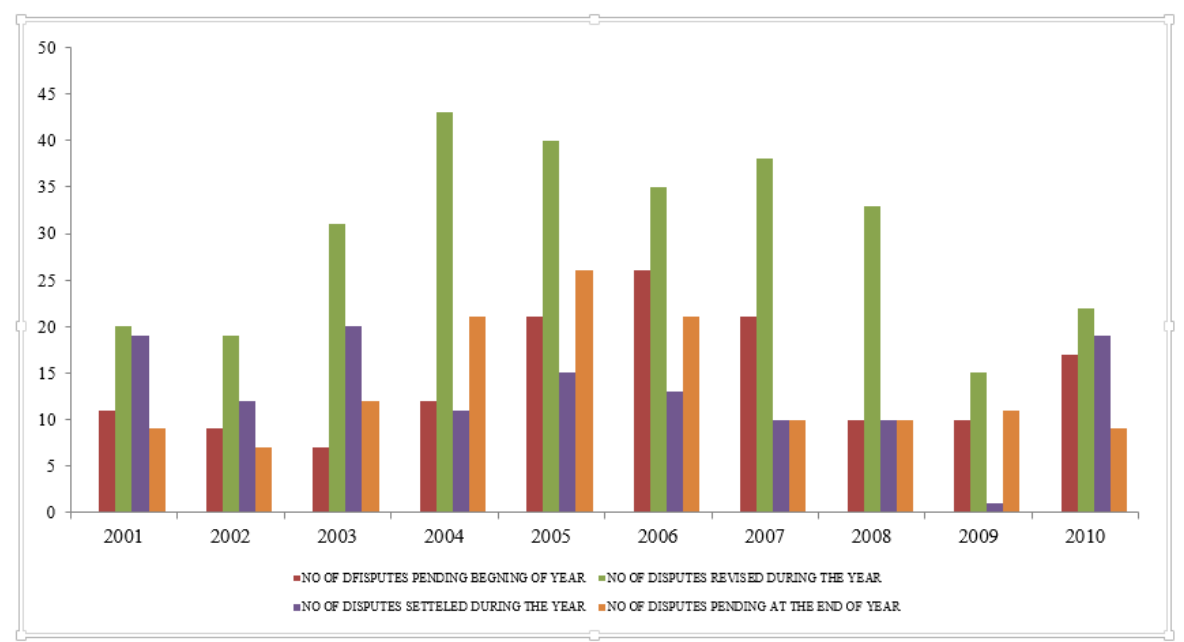

Source: Authors' elaborations

Fig. 1: Time Series Analysis Regarding Disputes

Fig. 2 depicts that the Jammu is appearing as the districts with highest numbers of disputes pending (113) in 2011-12 as compared to others. In Kathua, 22 disputes are been pending, Samba comprises of 8 , Udhampur 1, and rest of districts have not any dispute pending in the beginning of year.

While considering the parameters regarding the number of disputes revised, it has been found that 231 disputes are revised in Jammu, 38 in Kathua, 17 in Samba, 6 in Udhampur, 3 in Kisthwar, and 1 in Ramban. Ninety-two disputes were settled in Jammu, 17 in Kathua, 13 in Samba, 4 in Udhampur, 3 in Kisthwar and 1 in Ramban district, respectively.

The disputes that are not resolved are sent back to the government for resolution. It has been observed that 145 disputes in Jammu district are send back as a failure report. On the other hand, no failure report is being sent to the government in Kisthwar, Ramban and Udhampur district. The disputes pending at the end of the year are 105 in Jammu, 28 in Kathua, 2 in Udhampur and 1 in Samba, respectively.

Overall, it can be concluded from the figure that the highest numbers of disputes are found in Jammu district followed by Kathua, Samba, and Udhampur. In district Reasi, Ramban and Kisthwar least number of disputes have taken place. The reason behind the occurrence in large number of disputes in Jammu district is due to presence of large number of manufacturing units in various regions or in Jammu \& Kashmir State Industrial Development Corporations operational across different districts of the state.

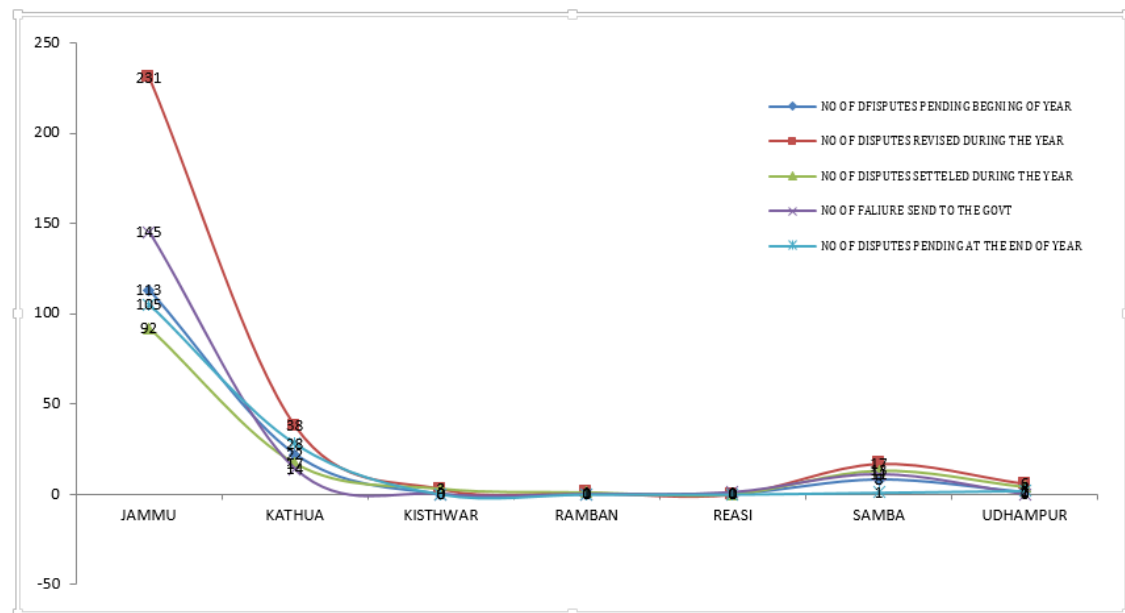

Source: Authors' elaborations

Fig. 2: District Wise Analysis for the Number of Disputes

The number of disputes received, pending and disposed under different acts namely Employee Compensation Act, Industrial Dispute Act, Minimum Wages Act, Payment and Gratuity Act and Payment and Wages Act have been highlighted in Fig. 3, 4, 5, 6 and 7 , respectively. A percentage wise analysis has been made for the disputes received, pending and 
disposed at the end of year in different acts over the period of time across industries in Jammu and Kashmir.

Fig. 3 depicts that under the Employee Compensation Act the number of disputes pending at the beginning of year have been on higher side than the number of disputes received and disposed off. It has further been highlighted from the figure that the number of disputes disposed has been on lower side in the initial years but a gradual improvement is observed during 2008 to 2010 and in the year 2011, the decline has again been depicted.

On the other hand, Fig. 4 provides the data on Industrial Dispute Act during the year 2003-2011. The number of pending disputes has decreased by 88.88 to 33.33 per cent during 2003 to 2011, whereas, in between it has also fluctuated. The numbers of received disputes have increased by 11.11 per cent to 66.66 per cent during 2003 to 2011 that is very high in number. The management has to make a major overlook in such issues that are responsible for the occurrence of disputes in the organisation and due to which the disputes received has been on higher side.

Furthermore, the number of disputes disposed increased from 38.89 per cent to 66.67 per cent during 2003-2010 then sudden decreased has been observed in 2011. It can be concluded that the disputes that are been disposed of in this act are depicting a sound industrial scenario in the state, but the management still require to maintain the industrial peace so that the issue that are turning up into disputes should always be on lower side of the scale. The results are in consonance with Sharma and Sidhu (2003); Verma and Kumar (1992), respectively.

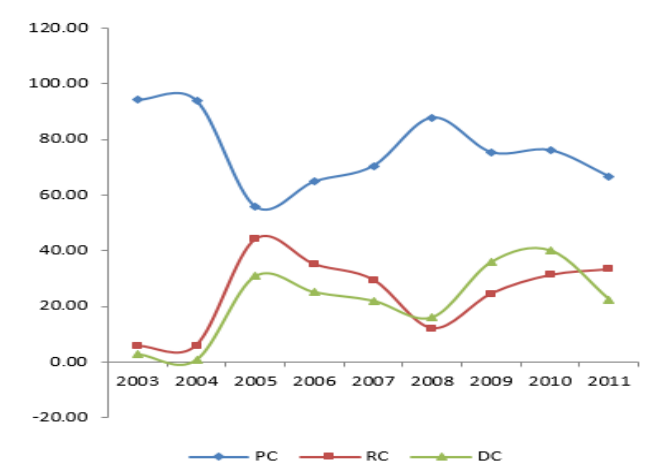

Source: Authors' elaborations

Fig. 3: Employee Compensation Act

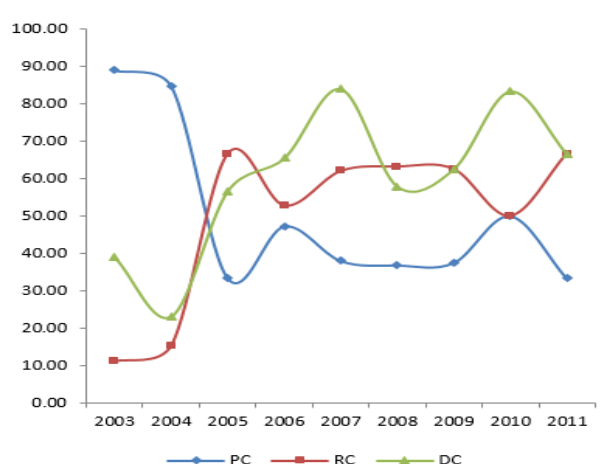

Source: Authors' elaborations

Fig. 4: Industrial Dispute Act

Fig. 5 mentions that the pending disputes of Minimum Wages Act have decreased from 100.00 per cent to 33.33 per cent from 2003 to 2011. The number of disputes received under Minimum Wages Act has showed an increase 66.66 per cent during 2003 to 2011.

Very interestingly the disputes that have been disposed under this particular act have also shown a steady path and are been successfully followed up with proper conclusions over the years. The disputes have initially increased up to 88.89 per cent during 20032010 but during the year 2011 these have totally settled down.

Taking into consideration the similar ground, Figure 6 highlighted the data in terms of Payment and Gratuity Act for the period of 2003-2011. The pending disputes under this act have decreased from 96.29 per cent in 2003 to 55.00 per cent in 2010 and then an increase by 75.00 per cent has been depicted in 2011 .

Interestingly, received cases increased from 3.70 per cent in 2003 to 47.79 per cent in 2009 and then a probable decline has measured in 2011 by 24.99 per cent. Alternatively, the disposed cases have depicted a cyclic trend over the years and it has been observed that an increase by 42.99 percent has been observed from the beginning to 2011 .

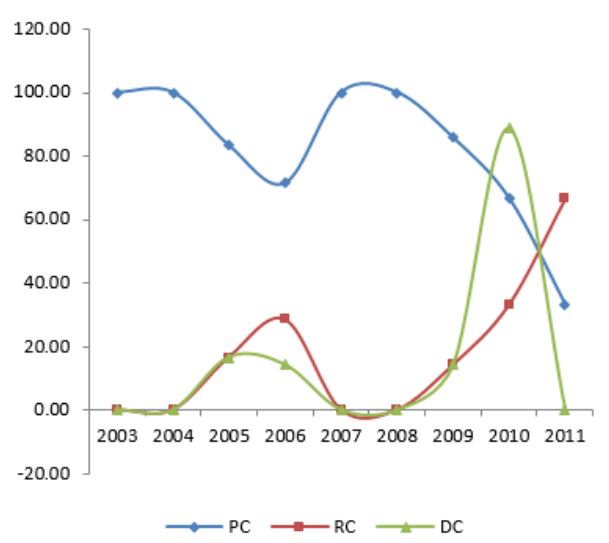

Source: Authors' elaborations

Fig. 5: Minimum Wages Act 


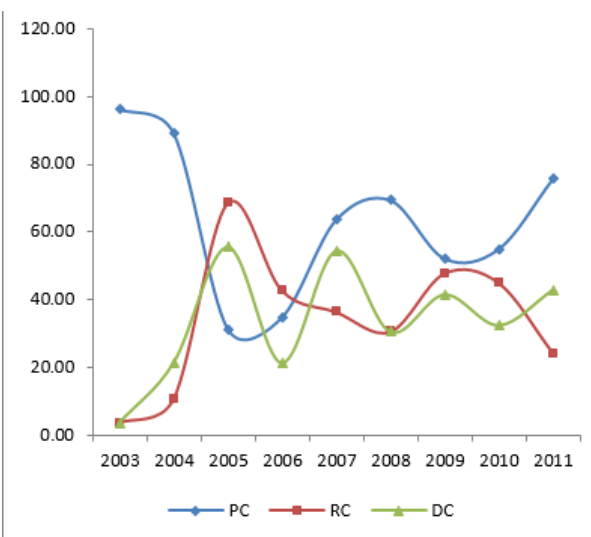

Source: Authors' elaborations

\section{Fig. 6: Payment and Gratuity Act}

Fig. 7 provides an insight for the data on Payment and Wages Act for the period 2003-2011. It has been observed from the data that the number of pending disputes have shown fluctuations during the years. Consequently, a decline has been depicted from 93.33 per cent in 2003 to 57.28 per cent during 2011. The received number of disputes has shown a contrary trend. An increase in the number of disputes received from 6.66 per cent in 2003 to 42.78 per cent in 2011 has been experienced. The disposed number of disputes has simultaneously increased from 7.14 per cent in 2003 to 58.46 per cent in 2011. It is clear from the data that regarding the payment of wages the disputes have not been solved in the proper and continuous manner. The disputes that have been received and the disputes with no solution have also shown continuous growth over the time. Keeping into view these statistical observations, it can be easily identified that the wage issue are the major concerns for the growth in the number of disputes in various industries across the $\mathbf{J} \&$ $\mathrm{K}$ state.

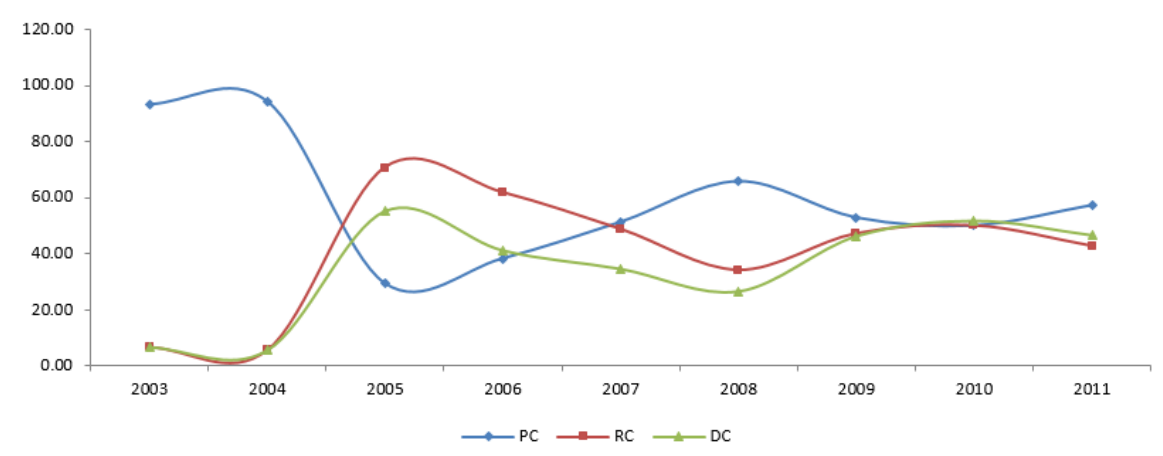

Source: Authors' elaborations

\section{Fig. 7: Payment and Wages Act}

\section{A Case of Cement Industry}

After evaluating the statistics regarding the industrial disputes in Jammu and Kashmir, the study focused on evaluating the responsible factor for the cause of disputes in J\&K state with special emphasis on Cement industry. The increasing complexities in the industries have created and widen the mutual trust among the employees and employers. It becomes pertinent to identify the probable reasons for the loss in the production, lockouts and increase in the gap between management and employees at the workplace. The disputes that are caused or occur in the industry can be segregated into economic and non-economic causes. The economic causes include Salary and incentive problems, Withdrawal of any concession or privilege, Leaves with wages and holidays, Bonus, profit sharing, Provident fund and gratuity and Dispute connected with minimum wages and allowances. On the other hand the non-economic causes takes into account the Dissatisfaction with company grievance handling policy, Wrongful discharge or dismissal of workmen, Hours of work and rest intervals, Retrenchment of workmen and closure of establishment, Political factors, Standing orders/Rules/Service Conditions/Safety measures, Non consultation with employees before key decisions affecting them are taken, Lack of effective mechanism for the prevention of conflict and Recruitment and Promotion policy, respectively.

It has been revealed from the Table 1 that respondents are disagree with the causes for disputes namely grievance handling policy of employer (47.6 per cent) followed by Wrongful discharge or dismissal of workmen (36.9 per cent), Withdrawal of any concession or privilege (32.4 per cent), Hours of work and rest intervals (37.9 per cent), Leaves with wages and holidays (45.5 per cent), Retrenchment of workmen and closure of establishment (35.5 per cent), Standing orders/Rules/Service Conditions/Safety measures (38.3 per cent), respectively. On the other hand, employee agree with handling of Salary and incentive problems by management ( 35.9 per cent); Bonus, profit sharing, Provident fund and gratuity provided by the employer (40.7 per cent); Dispute connected with minimum wages and allowances (58.6 per cent), Political factors 
(40.3 per cent), Lack of effective mechanism for the prevention of conflict (44.8 per cent) and Recruitment and Promotion policy of the employer (66.9 per cent), respectively in the cement industry the main cause of disputes. The similar results have been corroborated by Gani (1990), Singh (1983).

Table 1: Causes of Disputes

\begin{tabular}{|c|c|c|c|c|c|}
\hline Statements & SA & $\mathbf{A}$ & NAND & D & SD \\
\hline $\begin{array}{l}\text { Dissatisfaction with company } \\
\text { grievance handling policy }\end{array}$ & $\begin{array}{c}2 \\
(0.7)\end{array}$ & $\begin{array}{c}29 \\
(10.0)\end{array}$ & $\begin{array}{c}70 \\
(24.1)\end{array}$ & $\begin{array}{c}138 \\
(47.6)\end{array}$ & $\begin{array}{c}51 \\
(17.6)\end{array}$ \\
\hline Salary and incentive problems & $\begin{array}{c}128 \\
(44.1)\end{array}$ & $\begin{array}{c}104 \\
(35.9)\end{array}$ & $\begin{array}{c}49 \\
(16.9)\end{array}$ & $\begin{array}{c}4 \\
(1.4)\end{array}$ & $\begin{array}{c}5 \\
(1.7)\end{array}$ \\
\hline $\begin{array}{l}\text { Wrongful discharge or dismissal } \\
\text { of workmen }\end{array}$ & $\begin{array}{c}7 \\
(2.4)\end{array}$ & $\begin{array}{c}78 \\
(26.9)\end{array}$ & $\begin{array}{c}81 \\
(27.9)\end{array}$ & $\begin{array}{c}107 \\
(36.9)\end{array}$ & $\begin{array}{c}17 \\
(5.9) \\
\end{array}$ \\
\hline $\begin{array}{l}\text { Withdrawal of any concession or } \\
\text { privilege }\end{array}$ & $\begin{array}{c}16 \\
(5.5)\end{array}$ & $\begin{array}{c}77 \\
(26.6)\end{array}$ & $\begin{array}{c}91 \\
(31.4)\end{array}$ & $\begin{array}{c}94 \\
(32.4)\end{array}$ & $\begin{array}{c}12 \\
(4.1)\end{array}$ \\
\hline Hours of work and rest intervals & $\begin{array}{c}15 \\
(5.2)\end{array}$ & $\begin{array}{c}64 \\
(22.1)\end{array}$ & $\begin{array}{c}89 \\
(30.7)\end{array}$ & $\begin{array}{c}110 \\
(37.9)\end{array}$ & $\begin{array}{c}12 \\
(4.1)\end{array}$ \\
\hline Leaves with wages and holidays & $\begin{array}{c}12 \\
(4.1)\end{array}$ & $\begin{array}{c}58 \\
(20.0)\end{array}$ & $\begin{array}{c}63 \\
(21.7)\end{array}$ & $\begin{array}{c}132 \\
(45.5)\end{array}$ & $\begin{array}{c}25 \\
(8.6)\end{array}$ \\
\hline $\begin{array}{l}\text { Bonus, profit sharing, Provident } \\
\text { fund and gratuity }\end{array}$ & $\begin{array}{c}87 \\
(30.0) \\
\end{array}$ & $\begin{array}{c}118 \\
(40.7) \\
\end{array}$ & $\begin{array}{c}47 \\
(16.2) \\
\end{array}$ & $\begin{array}{c}23 \\
(7.9) \\
\end{array}$ & $\begin{array}{c}15 \\
(5.2) \\
\end{array}$ \\
\hline $\begin{array}{l}\text { Retrenchment of workmen and } \\
\text { closure of establishment }\end{array}$ & $\begin{array}{c}31 \\
(10.7) \\
\end{array}$ & $\begin{array}{c}62 \\
(21.4) \\
\end{array}$ & $\begin{array}{c}71 \\
(24.5) \\
\end{array}$ & $\begin{array}{c}103 \\
(35.5) \\
\end{array}$ & $\begin{array}{c}23 \\
(7.9) \\
\end{array}$ \\
\hline $\begin{array}{l}\text { Dispute connected with minimum } \\
\text { wages and allowances }\end{array}$ & $\begin{array}{c}170 \\
(58.6)\end{array}$ & $\begin{array}{c}45 \\
(15.5)\end{array}$ & $\begin{array}{c}18 \\
(6.2)\end{array}$ & $\begin{array}{c}34 \\
(11.7)\end{array}$ & $\begin{array}{c}23 \\
(7.9)\end{array}$ \\
\hline Political factors & $\begin{array}{c}117 \\
(40.3)\end{array}$ & $\begin{array}{c}93 \\
(32.1)\end{array}$ & $\begin{array}{c}28 \\
(9.7)\end{array}$ & $\begin{array}{c}25 \\
(8.6)\end{array}$ & $\begin{array}{c}27 \\
(9.3) \\
\end{array}$ \\
\hline $\begin{array}{l}\text { Standing orders/Rules/Service } \\
\text { Conditions/Safety measures }\end{array}$ & $\begin{array}{c}38 \\
(13.1)\end{array}$ & $\begin{array}{c}63 \\
(21.7)\end{array}$ & $\begin{array}{c}55 \\
(19.0)\end{array}$ & $\begin{array}{c}111 \\
(38.3)\end{array}$ & $\begin{array}{c}23 \\
(7.9)\end{array}$ \\
\hline $\begin{array}{l}\text { Non consultation with employees } \\
\text { before key decisions affecting } \\
\text { them are taken }\end{array}$ & $\begin{array}{c}87 \\
(30.0)\end{array}$ & $\begin{array}{c}72 \\
(24.8)\end{array}$ & $\begin{array}{c}15 \\
(5.2)\end{array}$ & $\begin{array}{c}57 \\
(19.7)\end{array}$ & $\begin{array}{c}59 \\
(20.3)\end{array}$ \\
\hline $\begin{array}{l}\text { Lack of effective mechanism for } \\
\text { the prevention of conflict }\end{array}$ & $\begin{array}{c}12 \\
(4.1)\end{array}$ & $\begin{array}{c}130 \\
(44.8)\end{array}$ & $\begin{array}{c}98 \\
(33.8)\end{array}$ & $\begin{array}{c}31 \\
(10.7)\end{array}$ & $\begin{array}{c}19 \\
(6.6)\end{array}$ \\
\hline Recruitment and Promotion policy & $\begin{array}{c}194 \\
(66.9)\end{array}$ & $\begin{array}{c}75 \\
(25.9)\end{array}$ & $\begin{array}{c}18 \\
(6.2)\end{array}$ & $\begin{array}{c}2 \\
(0.7)\end{array}$ & $\begin{array}{c}1 \\
(0.3)\end{array}$ \\
\hline
\end{tabular}

Note: Figures in the braces represent percentage values

Table 2: Descriptive Statistics of Causes of Disputes

\begin{tabular}{|l|c|c|c|}
\hline Statements & Mean & Std. Deviation & Variance \\
\hline $\begin{array}{l}\text { Dissatisfaction with company grievance } \\
\text { handling policy }\end{array}$ & 3.710 & 0.890 & 0.800 \\
\hline Salary and incentive problems & 1.810 & 0.890 & 0.790 \\
\hline Wrongful discharge or dismissal of workmen & 3.170 & 0.970 & 0.940 \\
\hline Withdrawal of any concession or privilege & 3.030 & 0.990 & 0.980 \\
\hline Hours of work and rest intervals & 3.140 & 0.980 & 0.960 \\
\hline Leaves with wages and holidays & 3.340 & 1.020 & 1.050 \\
\hline $\begin{array}{l}\text { Bonus, profit sharing, Provident fund and } \\
\text { gratuity }\end{array}$ & 2.180 & 1.100 & 1.220 \\
\hline $\begin{array}{l}\text { Retrenchment of workmen and closure of } \\
\text { establishment }\end{array}$ & 3.090 & 1.140 & 1.310 \\
\hline $\begin{array}{l}\text { Dispute connected with minimum wages and } \\
\text { allowances }\end{array}$ & 1.950 & 1.350 & 1.830 \\
\hline Political factors & 2.140 & 1.290 & 1.670 \\
\hline $\begin{array}{l}\text { Standing orders/Rules/Service } \\
\text { Conditions/Safety measures }\end{array}$ & 3.060 & 1.200 & 1.440 \\
\hline $\begin{array}{l}\text { Non consultation with employees before key } \\
\text { decisions affecting them are taken }\end{array}$ & 2.760 & 1.550 & 2.410 \\
\hline
\end{tabular}




\begin{tabular}{|l|c|c|c|}
$\begin{array}{l}\text { Lack of effective mechanism for the prevention } \\
\text { of conflict }\end{array}$ & 2.710 & 0.950 & 0.900 \\
\hline Recruitment and Promotion policy & 1.420 & 0.670 & 0.450 \\
\hline
\end{tabular}

To have a comprehensive overview about the respondent response towards the various economic and non-economic causes of disputes, the study focused on deriving the descriptive statistics of the statements used to measure the perception. The descriptive analysis has also been developed to determine the distribution of the response provided by the respondents towards various causes of disputes in cement industry in J\&K. After evaluating the statistics regarding the industrial disputes in Jammu and Kashmir, the study have also focused on evaluating the responsible factor for the cause of disputes in J\&K state with special emphasis on Cement industry. The descriptive statistics of the table provide the interesting and vital conclusions regarding the causes of disputes for cement industry in Jammu and Kashmir. The results from the Table 2 reveals that the most essential and responsible factor for the causes of disputes in cement industry in $\mathrm{J} \& \mathrm{~K}$ state is recruitment and promotion policy (Mean $=1.42, \mathrm{SD}=0.67$, Variance $=0.45$ ) followed by salary and incentive problems $($ Mean $=1.81, \mathrm{SD}=0.89$, Variance $=0.79)$ and disputes connected with minimum wages and allowances (Mean $=1.950, \mathrm{SD}=1.350$, Variance $=1.83$ ), respectively. Thus, it can be concluded from the table that the factors that are responsible for the occurrence of disputes in cement industry in J\&K are mostly under the power and influence of the management personnel only. Therefore, it is can be suggested to these firms that the focus should be on these two factor primarily in order to have the least number of man days lost thereby, helping the firms in making the industrial harmony and focusing on the production. In addition to this, the present study also provide an insight about the least responsible factor i.e. company grievance handling policy with $(\mathrm{Mean}=3.71, \mathrm{SD}=0.89$, Variance 0.80 ). The results are in opposite to the Nagaraju (1981); Murthy et al. (1986) and Asdhir (1987).

\section{Conclusion and Recommendations}

The study concluded that over the period of time there has been gradual decline observed in the number of disputes in $\mathrm{J} \& \mathrm{~K}$ but it has been experienced from the statistics that Jammu division is showing the presence of more disputes than other districts of the state. The reason behind this may be due to the presence of large number of small enterprises in the districts that are in the disputes very often than the medium and large enterprise. The study further reveled that there have not been an effective settlement of disputes that come under different acts in J\&K. It has been observed that the settlement machinery mechanism might have some errors due to which the disputes that fall under the various acts involved in the present endeavor are not been settled out at the pace and thereby confirming that the management or the third party contribution in the settlement is not very effective in J\&K. The conclusions are in corroboration with Katuwal (2011).

The policy maker should also be able to tackle out the issues regarding the wages and promotions of the employees working in the cement industry in Jammu and Kashmir. These results have been very much close to the theory that also provides the information regarding the major influential factor for the causes of disputes in different economies. The interesting results from the present study depicts that the promotion and recruitment issues are the most important factor than the wages for the cause of dispute in $J \& K$ state. Moreover, the result highlights that the primary contribution for the cause of disputes in the cement industries operating in Jammu and Kashmir are economic causes rather than non-economic causes. One of the primary reasons for this result may be the engagement of labour class people for the short duration in the cement manufacturing companies by the employer and adequate availability of cheap and easily available workforce in the state. Thus, the policy makers of the state should keep into consideration the view over the unethical practices and the less focus of employer for the workforce especially in context with the economic concerns in the enterprises.

\section{References}

1. Asdhir, V. "Industrial Relations in India", New Delhi: Deep and Deep Publications, (1987).

2. Bhalotra, S. "The Puzzle of Jobless Growth in Indian Manufacturing", Oxford Bulletin of Economics and Statistics, (1998) 60:15-32.

3. Dutta Roy, S. "Employment Dynamics in Indian Industry: Adjustment Lags and the Impact of Job Security Regulations", Journal of Development Economics, (2004) 73, 233-56.

4. Gani, A. "Industrial Relations in Jammu and Kashmir", Indian Journal of Industrial Relations, (1990) 26, 53-67.

5. Islam, M. M. "Industrial relations in Bangladesh." Indian Journal of Industrial Relations, (1893) 19, 161-189

6. Katuwal, S.B. "Legal Provision for the Settlement of Industrial Disputes in Nepal", International Journal of Research in Finance \& Marketing, (2011) 1, 41-57

7. Khurana, S.K. "A Comparative Analysis of Industrial Relations in Private and Public sector Industry in India", Indian Journal of Industrial Relations, (1972) 7, 411-431.

8. Kumar, P. "The Working of Conciliation Machinery in Rajasthan”, Indian Journal of Industrial Relations, (1966) 2, 41-47.

9. Ministry of Finance. "Economic Survey 2005-06”, Government of India, (2006)

10. Murthy, B.S., Giri, D.V. and Rath, B.P. "Conciliation Machinery in Orissa: A Study". The Indian Journal of Industrial Relations, (1986) 21,428-447

11. Nagaraju, S. Industrial Relations System in India. Allahabad: Chugh publications, (1981). 
12. Pathania, R. "Industrial Relations in India in the era of Liberalization", IOSR Journal of Humanities and Social Science, (2012) 2,22-26.

13. Sharma and Sidhu, A. S. "Industrial Disputes in Punjab: Emerging Trends", Indian Journal of Industrial Relations, (2003) 39, 58-83

14. Singh, M. K. "Industrial Relations in Maharashtra", Indian Journal of Industrial Relations, (1983) 4,549-567

15. Verma, P. and Kumar, K. "Industrial Conflicts: A Statistical Analysis", Vikalpa, (1992) 3,11-24 